[I 19.2:St $8 / 3]$

Estimating the Magnitude of Peak Discharges

for Selected Flood Frequencies on Small

Streams in East Texas

UNITED STATES DEPARTMENT OF THE INTERIOR Geological Survey
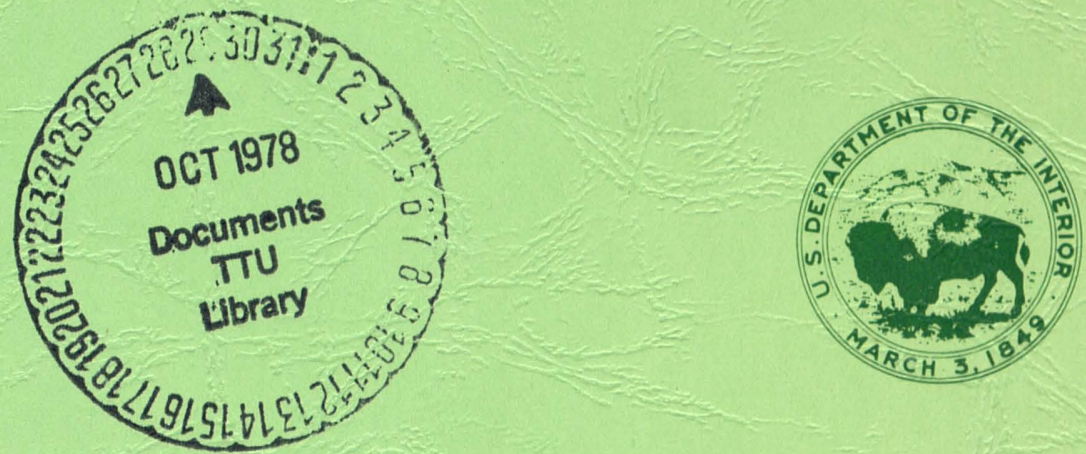

Prepared by the U. S. Geological Survey in cooperation with the Texas

Highway Department and the U. S. Department of Transportation, Federal Highway Administration 

UNITED STATES DEPARTMENT OF THE INTERIOR GEOLOGICAL SURVEY

Research Study No. 4-5-65-85, Interim Report No. 85-8

ESTIMATING THE MAGNITUDE OF PEAK DISCHARGES FOR SELECTED FLOOD FREQUENCIES

ON SMALL STREAMS IN EAST TEXAS

By

E. E. Schroeder

U.S. Geological Survey

Open-File Report

Prepared by the U.S. Geological Survey

in cooperation with the

Texas Highway Department and

the U.S. Department of Transportation,

Federal Highway Administration

February 1974 

Abstract-1-

Introduction-1.

Related studies-...

Range of application-1 3

Techniques-... 3

Method of analysis-_. 5

Metric conversions-_. 11

Summary-1.- 15

References cited-1. 16

\section{ILLUSTRATIONS}

Figure 1. Map showing locations of stream-gaging stations-_-_--- 4

2. Nomograph for determining peak discharges for

floods with a 10-year recurrence interval-...... 12

3. Nomograph for determining peak discharges for

floods with a 25-year recurrence interval-_...... 13

4. Nomograph for determining peak discharges for

floods with a 50-year recurrence interval-_...- 14

\section{TABLES}

Table 1. Variables used in regression equations for 28 stations with long-term (10-33 years) records-....-

2. Variables used in regression equations for 60 stations with short-term (less than 10 years) records 



\title{
ESTIMATING THE MAGNITUDE OF PEAK DISCHARGES \\ FOR SELECTED FLOOD FREQUENCIES ON \\ SMALL STREAMS IN EAST TEXAS
}

\author{
By \\ E. E. Schroeder \\ U.S. Geological Survey
}

\begin{abstract}
Peak-discharge data from 28 stream-gaging stations with long-term records (10-33 years) and 60 stations with short-term records (less than 10 years) were used in multiple linear-regression procedures to obtain equations for estimating the peak discharge of floods with recurrence intervals of 10,25 , and 50 years on small rural streams in East Texas. The significant independent variables were drainage area, channel slope, and channel length. The relationships are presented in nomographs that can be used for estimating the peak discharges on small streams for floods of the selected recurrence intervals, provided that the magnitude of the independent variables is within the range of those used to develop the relationships.
\end{abstract}




\section{INTRODUCTION}

A program with the objective of obtaining basic hydrologic data to define the magnitude and frequency of floods for small drainage areas in Texas was begun by the U.S. Geological Survey in September 1964. This program is financed by funds made available for research by the Texas Highway Department and the U.S. Department of Transportation, Federal Highway Administration. This preliminary report, which has been prepared as part of the continuing program, presents an improved method for estimating peak discharges for floods with recurrence intervals of 10,25 , and 50 years on small rural streams in East Texas.

For the convenience of readers who may want to use metric units, the metric equivalents are given in parentheses following the English units. Data presented in the tables may be converted by using the following conversion factors:

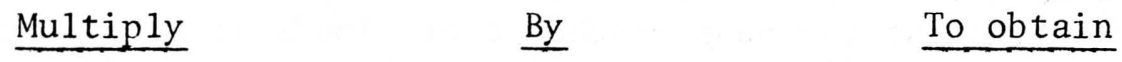

Miles (mi)

Feet ( $\mathrm{ft}$ )

Square miles $\left(\mathrm{mi}^{2}\right)$

1.609

.3048

Kilometers (km)

Cubic feet per second $\left(\mathrm{ft}^{3} / \mathrm{s}\right) \quad .028317$

Feet per mile

Meters (m)

Square kilometers $\left(\mathrm{km}^{2}\right)$

Cubic meters per second $\left(\mathrm{m}^{3} / \mathrm{s}\right)$

Meters per kilometer

\section{RELATED STUDIES}

Two separate studies recently completed by the U.S. Geological Survey have produced flood-frequency equations that can be used in specific locations. Johnson and Sayre (1973) computed a set of equations that are applicable to the Houston metropolitan area for drainage basins that range from 0.3 to 100 square miles ( 0.7 to 259 square kilometers) and have impervious areas that range from 1 to 40 percent. In a study of urban hydrology of the Dallas metropolitan area, Dempster (1974) computed a set of equations that can be applied to drainage basins that range from 1 to 100 square miles (2.6 to 259 square kilometers) and have impervious areas that range from 1 to about 50 percent. Both sets of equations were developed to compute runoff from urban areas; however, they can be applied to rural areas by setting "impervious area" equal to 1 percent.

In local areas such as Houston or Dallas, the equations developed for these areas may produce more reliable estimates than the regional equations that are presented in this report. 
Gilbert and Hawkinson (1971) developed a set of equations for larger rural drainage basins that resated flood peaks to drainage area, slope, precipitation, and temperature. That work was done as part of a dataevaluation study, however, and the equations were not proposed for use by designers and planners.

Previous studies by Benson (1964) and Patterson (1965) also defined flood-peak estimating relations applicable to larger rural drainage areas. However, the relations defined in the study described in this report were based upon a longer period of flood records collected at sites sampling a wider range of watershed characteristics.

\section{RANGE OF APPLICATION}

The relationships presented in this report are applicable to the part of Texas generally east of longitude $98 \mathrm{~W}$. , an area of approximately 100,000 square miles $(259,000$ square kilometers). The locations of the data-collection sites are shown on figure 1. The drainage areas above these sites ranged from about 0.1 to about 120 square miles $(0.26$ to 310 square kilometers). Channel slopes generally ranged from 1.9 to 200 feet per mile (0.35 to 38 meters per kilometer). The relationships are applicable to all nonregulated, natural rural streams in East Texas whose drainage areas and slopes are within these ranges; the relationships should not be extrapolated.

\section{TECHNIQUES}

The final relations (equations) presented in this report were obtained by multiple linear-regression techniques. This technique has been known for many years, but it did not receive widespread use until the age of the electronic computer because of the tedious calculations necessary for solution.

Multiple linear regression is a procedure that will develop a relation for calculating a predicted value for the dependent variable (the selected T-year flood) from one or more independent variables. The independent variables that remained significant after regression were drainage area, channel slope, and channel length.

Where $\mathrm{A}$ is drainage area, in square miles, determined by use of a planimeter;

$S$ is the average slope, in feet per mile, between points 10 and 85 percent of the distance from the site to the basin divide; and

$L$ is the length, in miles, of the main channel between the site and the basin divide measured along the channel that drains the largest area.

Linearity was achieved by a logarithmic transformation of the variables. 


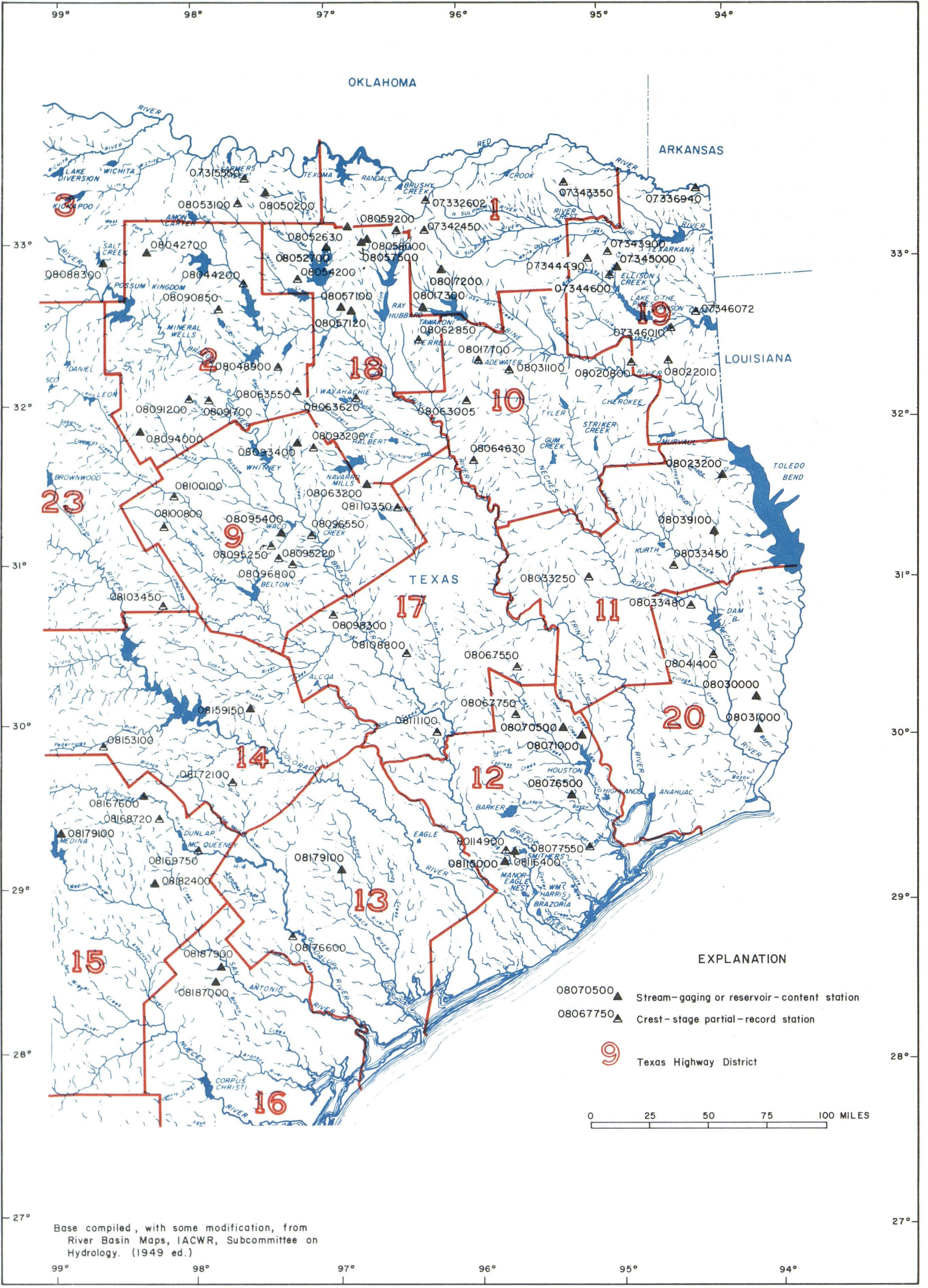

FIGURE 1. - Locations of stream-gaging stations 
Annual peak data from 28 stations with drainage areas ranging from 1.26 to 123 square miles (3.26 to 318 square kilometers) and with periods of record ranging from 10 to 33 years were used to determine the peak discharges of floods with recurrence intervals of 10,25 , and 50 years at each station. These discharges were computed by using the log-Pearson Type III distribution. A few of the stations had unrealistic skew coefficients; therefore, frequency curves for these stations were prepared graphically by the U.S. Geological Survey on the basis of experience and engineering judgment. Discharge values were taken from the curves.

These discharges were then used as the dependent variables in a multiple-regression analysis to compute the relationships for the ratio of the 50-year discharge to the 10-year discharge and also the ratio of the 25-year discharge to the 10-year discharge. The variables used for this analysis are shown in table 1 . Values of the independent variables were determined from U.S. Geological Survey topographic maps (scale $1: 24,000)$.

The results of the analysis are as follows:

$$
\begin{aligned}
& \frac{Q_{50}}{Q_{10}}=\frac{1.84 A^{0.284}}{L^{0.377}} \text { and } \\
& \frac{Q_{25}}{Q_{10}}=\frac{1.465 \mathrm{~A}^{0.17}}{L^{0.229}}
\end{aligned}
$$

where $\frac{Q_{50}}{Q_{10}}=$ the ratio of the 50 -year discharge to the 10-year discharge;

$$
\begin{aligned}
1.84 & =\text { a constant; } \\
\frac{Q_{25}}{Q_{10}} & =\text { the ratio of the } 25 \text {-year discharge to the } 10 \text {-year discharge; } \\
1.465 & =\text { a constant; } \\
\mathrm{A} & =\text { drainage area, in square miles; and } \\
\mathrm{L} & =\text { main-channe1 length, in miles. }
\end{aligned}
$$

The standard errors of these relationships were 16 percent and 11 percent, respectively. These relationships are regional, and it is assumed that they are applicable to all small rural streams in the area, provided that the magnitude of the independent variables is within the range of those used to develop the relationships. 
Table 1.--Variables used in regression equations for 28 stations with long-term (10-33 years) records

\begin{tabular}{|c|c|c|c|c|c|c|}
\hline Station & $\begin{array}{c}\text { Drainage } \\
\text { area } \\
\left(\mathrm{mi}^{2}\right)\end{array}$ & $\begin{array}{c}\text { Channel } \\
\text { slope } \\
\text { (ft per mi) }\end{array}$ & $\begin{array}{l}\text { Channe1 } \\
\text { length } \\
\text { (mi) }\end{array}$ & $\begin{array}{c}\text { Peak discharge at } \\
\text { 10-year recurrence } \\
\text { interval } \\
\left(\mathrm{ft}^{3} / \mathrm{s}\right)\end{array}$ & $\begin{array}{c}\text { Peak discharge at } \\
\text { 25-year recurrence } \\
\text { interval } \\
\left(\mathrm{ft}^{3} / \mathrm{s}\right) \\
\end{array}$ & $\begin{array}{c}\text { Peak discharge at } \\
50-\text { year recurrence } \\
\text { interval } \\
\left(\mathrm{ft}^{3} / \mathrm{s}\right)\end{array}$ \\
\hline 07345000 & 72.00 & 6.49 & 19.20 & 11,800 & 19,700 & 27,600 \\
\hline 08017200 & 77.70 & 7.88 & 21.00 & 17,600 & -- & -- \\
\hline 08017300 & 78.70 & 8.37 & 12.00 & 23,600 & -- & -- \\
\hline 08023200 & 97.80 & 7.52 & 19.30 & 10,200 & 16,600 & 22,900 \\
\hline 08024500 & 123.00 & 7.40 & 22.40 & 14,100 & 23,800 & -- \\
\hline 08030000 & 69.20 & 4.79 & 19.00 & 4,860 & 6,290 & 7,390 \\
\hline 08031000 & 83.30 & 1.91 & 26.60 & 3,740 & 5,380 & 6,860 \\
\hline 08039100 & 89.00 & 6.14 & 26.00 & 11,500 & -- & -- \\
\hline 08042700 & 21.60 & 23.90 & 10.70 & 5,230 & 7,350 & -- \\
\hline 08052700 & 75.50 & 8.20 & 24.40 & 9,710 & 13,300 & -- \\
\hline 08057100 & 29.40 & 15.20 & 13.50 & 15,350 & 20,100 & 23,630 \\
\hline 08057120 & 6.77 & 36.60 & 4.88 & 5,030 & 6,420 & 7,410 \\
\hline 08057500 & 2.14 & 104.80 & 1.40 & 1,580 & 2,170 & 2,620 \\
\hline 08058000 & 1.26 & 66.20 & 1.50 & 1,320 & 1,700 & 1,950 \\
\hline 08070500 & 105.00 & 8.14 & 28.80 & 9,990 & 15,800 & 21,300 \\
\hline 08071000 & 117.00 & 7.58 & 27.40 & 7,250 & 14,150 & 22,000 \\
\hline 08076500 & 24.70 & 4.41 & 19.00 & 3,340 & 4,080 & 4,640 \\
\hline 08094000 & 3.34 & 37.00 & 2.80 & 2,900 & 4,950 & -- \\
\hline 08095400 & 78.20 & 16.40 & 34.70 & 18,800 & -- & -- \\
\hline 08096800 & 5.04 & 64.60 & 3.65 & 3,730 & 5,570 & -- \\
\hline 08098300 & 22.80 & 10.80 & 13.30 & 7,980 & -- & 15,700 \\
\hline 08115000 & 42.30 & 2.61 & 15.00 & 6,120 & 8,850 & 11,200 \\
\hline 08160000 & 1.48 & 69.60 & 1.80 & 1,320 & 1,930 & 2,420 \\
\hline 08163500 & 108.00 & 9.41 & 24.00 & 26,100 & 40,900 & 54,800 \\
\hline 08179100 & 56.30 & 36.40 & 13.00 & 21,400 & 35,600 & -- \\
\hline 08182400 & 7.01 & 35.40 & 3.70 & 3,430 & 5,540 & -- \\
\hline 08187000 & 3.29 & 52.70 & 2.25 & 3,070 & 4,530 & -- \\
\hline 08187900 & 8.43 & 24.20 & 3.70 & 2,580 & -- & - \\
\hline
\end{tabular}


Annual peak data from 60 short-term stations were used to determine the peak discharge for floods with a 10-year recurrence interval at each of these sites. These discharges were all determined graphically. The peak discharges for floods with a 10-year recurrence interval (dependent variable) and the independent variables--drainage area, channel slope, and channel length for each of the 60 sites are listed in table 2 .

A regional 10-year frequency relationship was developed by multipleregression analysis by using the 10-year peak discharges from the records of both the 60 short-term stations and the 28 long-term stations as the dependent variables. The standard error of this regression was 48 percent. Values of A, S, and L were obtained from U.S. Geological Survey topographic maps (scale $1: 24,000)$. The resulting equation follows:

$$
Q_{10}=\frac{260 \mathrm{~A}^{1.304} \mathrm{~S}^{0.302}}{\mathrm{~L}^{0.824}}
$$

where $Q_{10}=$ the 10 -year discharge, in cubic feet per second;

$260=$ the constant;

$\mathrm{A}=$ the drainage area, in square miles;

$\mathrm{L}=$ the length, in miles, of the main channel between the site and the basin divide, measured along the channel that drains the largest area; and

$\mathrm{S}=$ the average slope, in feet per mile, between points 10 and 85 percent of the distance along the main channel from the site to the basin divide.

Additional $Q_{10}$ equations developed by the regression analysis and the standard error of the regression are as follows:

$$
\begin{array}{ll}
Q_{10}=113 \mathrm{~A}^{0.864} \mathrm{~S}^{0.405} & (52 \text { percent }) \\
Q_{10}=\frac{993 \mathrm{~A}^{1.347}}{\mathrm{~L}^{1.124}} & (53 \text { percent }) \\
Q_{10}=551 \mathrm{~A}^{0.684} & (61 \text { percent })
\end{array}
$$

The final step was to multiply the regional 10-year equation by each of the two ratio equations to give single equations for the 50-year and 25-year discharge as follows:

(a11 data)

$$
Q_{50}=Q_{10} \frac{Q_{50}}{Q_{10}}
$$

(28 long-term stations )

$$
Q_{10}=\frac{260 \mathrm{~A}^{1.304} \mathrm{~S}^{0.302}}{\mathrm{~L}^{0.824}}
$$

$$
\frac{Q_{50}}{Q_{10}}=\frac{1.84 A^{0.284}}{L^{0.377}}
$$


Table 2.--Variables used in regression equations for 60 stations with short-term (less than 10 years) records

\begin{tabular}{|c|c|c|c|c|}
\hline Station & $\begin{array}{c}\text { Drainage } \\
\text { area } \\
\left(\mathrm{mi}^{2}\right)\end{array}$ & $\begin{array}{c}\text { Channe1 } \\
\text { slope } \\
\text { (ft per mi) }\end{array}$ & $\begin{array}{l}\text { Channel } \\
\text { length } \\
\text { (mi) }\end{array}$ & $\begin{array}{c}\text { Peak discharge at } \\
\text { 10-year recurrence } \\
\text { interval } \\
\left(\mathrm{ft}^{3} / \mathrm{s}\right)\end{array}$ \\
\hline 07315550 & 0.82 & 51.20 & 2.85 & 255 \\
\hline 07322602 & 6.21 & 23.30 & 4.80 & 3,200 \\
\hline 07336940 & 3.33 & .80 & 6.45 & 280 \\
\hline 07342450 & .22 & 66.60 & .78 & 210 \\
\hline 07343350 & 1.00 & 45.00 & 1.45 & 1,000 \\
\hline 07343900 & .78 & 87.20 & 1.03 & 700 \\
\hline 07344490 & 4.27 & 26.90 & 3.60 & 1,650 \\
\hline 07344600 & 7.11 & 20.30 & 6.80 & 760 \\
\hline 07346010 & .21 & 73.20 & .75 & 80 \\
\hline 07346072 & .73 & 57.10 & 1.40 & 365 \\
\hline 08017700 & .33 & 21.70 & .80 & 255 \\
\hline 08020800 & 5.05 & 24.80 & 4.15 & 1,100 \\
\hline 08022010 & .46 & 108.10 & 1.15 & 360 \\
\hline 08031100 & 1.09 & 37.76 & 1.90 & 465 \\
\hline 08033250 & 1.17 & 25.40 & 2.30 & 480 \\
\hline 08033450 & .52 & 63.90 & 1.30 & 280 \\
\hline 08033480 & .15 & 200.00 & .80 & 62 \\
\hline 08041400 & 5.03 & 23.90 & 4.40 & 700 \\
\hline 08044200 & 2.95 & 45.40 & 3.35 & 1,600 \\
\hline 08048900 & 5.86 & 27.60 & 5.40 & 1,300 \\
\hline 08050200 & .77 & 60.80 & 1.90 & 720 \\
\hline 08052630 & 2.04 & 37.30 & 2.52 & 2,500 \\
\hline 08053100 & 1.70 & 78.50 & 2.35 & 830 \\
\hline
\end{tabular}


Table 2.--Variables used in regression equations for 60 stations with short-term (less than 10 years) records--Continued

\begin{tabular}{|c|c|c|c|c|}
\hline Station & $\begin{array}{l}\text { Drainage } \\
\text { area } \\
\left(\mathrm{mi}^{2}\right)\end{array}$ & $\begin{array}{c}\text { Channel } \\
\text { slope } \\
\text { (ft per mi) }\end{array}$ & $\begin{array}{l}\text { Channel } \\
\text { length } \\
\text { (mi) }\end{array}$ & $\begin{array}{c}\text { Peak discharge at } \\
\text { 10-year recurrence } \\
\text { interval } \\
\left(\mathrm{ft}^{3} / \mathrm{s}\right)\end{array}$ \\
\hline 08054200 & 0.50 & 89.40 & 0.88 & 280 \\
\hline 08059200 & .52 & 86.00 & 1.00 & 580 \\
\hline 08062850 & 12.96 & 8.00 & 12.00 & 2,420 \\
\hline 08063005 & .90 & 40.30 & 1.66 & 640 \\
\hline 08063180 & .72 & 39.60 & 1.28 & 620 \\
\hline 08063200 & 17.60 & 15.50 & 8.00 & 5,300 \\
\hline 08063550 & .84 & 49.50 & 1.42 & 880 \\
\hline 08063620 & .62 & 44.30 & 1.18 & 610 \\
\hline 08064630 & .22 & 93.00 & .57 & 118 \\
\hline 08067550 & 2.35 & 19.80 & 4.70 & 480 \\
\hline 08067750 & .13 & 171.40 & .47 & 138 \\
\hline 08077550 & 18.00 & 4.70 & 8.05 & 1,370 \\
\hline 08088300 & 19.70 & 17.10 & 11.00 & 1,815 \\
\hline 08090850 & 3.37 & 48.60 & 5.65 & 540 \\
\hline 08091200 & .06 & 382.00 & .23 & 120 \\
\hline 08091700 & 7.82 & 48.30 & 5.00 & 3,000 \\
\hline 08093400 & 11.70 & 20.70 & 10.70 & 3,300 \\
\hline 08093200 & .36 & 70.60 & .85 & 390 \\
\hline 08095220 & 15.90 & 28.40 & 6.14 & 4,200 \\
\hline 08095250 & 2.52 & 24.10 & 3.55 & 740 \\
\hline 08096550 & .40 & 60.00 & .80 & 320 \\
\hline 08100100 & 2.91 & 54.50 & 4.03 & 820 \\
\hline 08100800 & 5.56 & 49.00 & 5.50 & 1,840 \\
\hline
\end{tabular}


Table 2.--Variables used in regression equations for 60 stations with short-term (1ess than 10 years) records--Concluded

\begin{tabular}{|c|c|c|c|c|}
\hline Station & $\begin{array}{l}\text { Drainage } \\
\text { area } \\
\left(\mathrm{mi}^{2}\right)\end{array}$ & $\begin{array}{c}\text { Channel } \\
\text { slope } \\
\text { (ft per mi) }\end{array}$ & $\begin{array}{l}\text { Channe1 } \\
\text { length } \\
\text { (mi) }\end{array}$ & $\begin{array}{c}\text { Peak discharge at } \\
\text { 10-year recurrence } \\
\text { interval } \\
\left(\mathrm{ft}^{3} / \mathrm{s}\right)\end{array}$ \\
\hline 08103450 & 1.08 & 74.70 & 2.00 & 620 \\
\hline 08108800 & .14 & 109.00 & .43 & 128 \\
\hline 08110350 & 4.42 & 14.80 & 5.25 & 2,480 \\
\hline 08111100 & .75 & 37.50 & 1.28 & 515 \\
\hline 08114900 & 5.70 & 3.27 & 5.30 & 630 \\
\hline 08116400 & 8.53 & 2.34 & 6.80 & 1,610 \\
\hline 08153100 & 1.37 & 58.60 & 3.35 & 165 \\
\hline 08159150 & 4.61 & 35.50 & 3.35 & 1,390 \\
\hline 08167600 & 10.91 & 66.80 & 5.90 & 4,600 \\
\hline 08168720 & .48 & 142.60 & 1.25 & 500 \\
\hline 08169750 & 5.46 & 13.50 & 4.75 & 870 \\
\hline 08169850 & .24 & 110.80 & .87 & 190 \\
\hline 08172100 & .44 & 106.40 & .84 & 400 \\
\hline 08176600 & .48 & 36.70 & .80 & 278 \\
\hline
\end{tabular}


In equation 7 , replace $Q_{10}$ and $\frac{Q_{50}}{Q_{10}}$ with equation 8 and equation 1
respectively, and

$$
Q_{50}=\frac{260 \mathrm{~A}^{1.304 S^{0.302}}}{L^{0.824}} \frac{1.84 \mathrm{~A}^{0.284}}{\mathrm{~L}^{0.377}}
$$

combine terms and

$$
Q_{50}=\frac{478.4 \mathrm{~A}^{1.588} \mathrm{~S}^{0.302}}{\mathrm{~L}^{1.201}}
$$

similarly

resulting in

$$
Q_{25}=Q_{10} \frac{Q_{25}}{Q_{10}}
$$

$$
Q_{25}=\frac{380.9 A^{1.475} S^{0.302}}{L^{1.053}}
$$

The residuals for these equations were plotted and no overall bias nor areal trends were indicated.

A11 of the equations are presented in nomographic form on figures 2, 3, and 4. The nomographs provide a graphical method for determining discharges without having to make mathematical calculations. The standard errors (SE) for the 25-year and 50-year equations were computed as follows:

$$
\begin{aligned}
& (\mathrm{SE})_{25}=\left((\mathrm{SE})_{10}^{2}+(\mathrm{SE})_{\frac{25}{10}}^{2}\right)^{\frac{1}{2}} \text {, and } \\
& (\mathrm{SE})_{50}=\left((\mathrm{SE})_{10}^{2}+(\mathrm{SE})_{\frac{50}{10}}^{2}\right)^{\frac{1}{2}}
\end{aligned}
$$

where (SE) is the logarithmic value of the standard error. These values, converted to percentage, are 49 percent and 50 percent, respectively.

\section{METRIC CONVERSIONS}

Equations (3), (4), (5), (6), (9), and (10) may be converted to the International (metric) System of Units by use of the following forms:

$$
\begin{aligned}
& Q_{10}=\frac{5.20 \mathrm{~A}^{1.304 \mathrm{~S}^{0.302}}}{\mathrm{~L}^{0.824}}\left(\mathrm{~m}^{3} / \mathrm{s}\right) \\
& Q_{10}=2.755 A^{0.864} \mathrm{~S}^{0.405}\left(\mathrm{~m}^{3} / \mathrm{s}\right) \\
& Q_{10}=\frac{13.318 \mathrm{~A}^{1.347}}{\mathrm{~L}^{1.124}}\left(\mathrm{~m}^{3} / \mathrm{s}\right)
\end{aligned}
$$




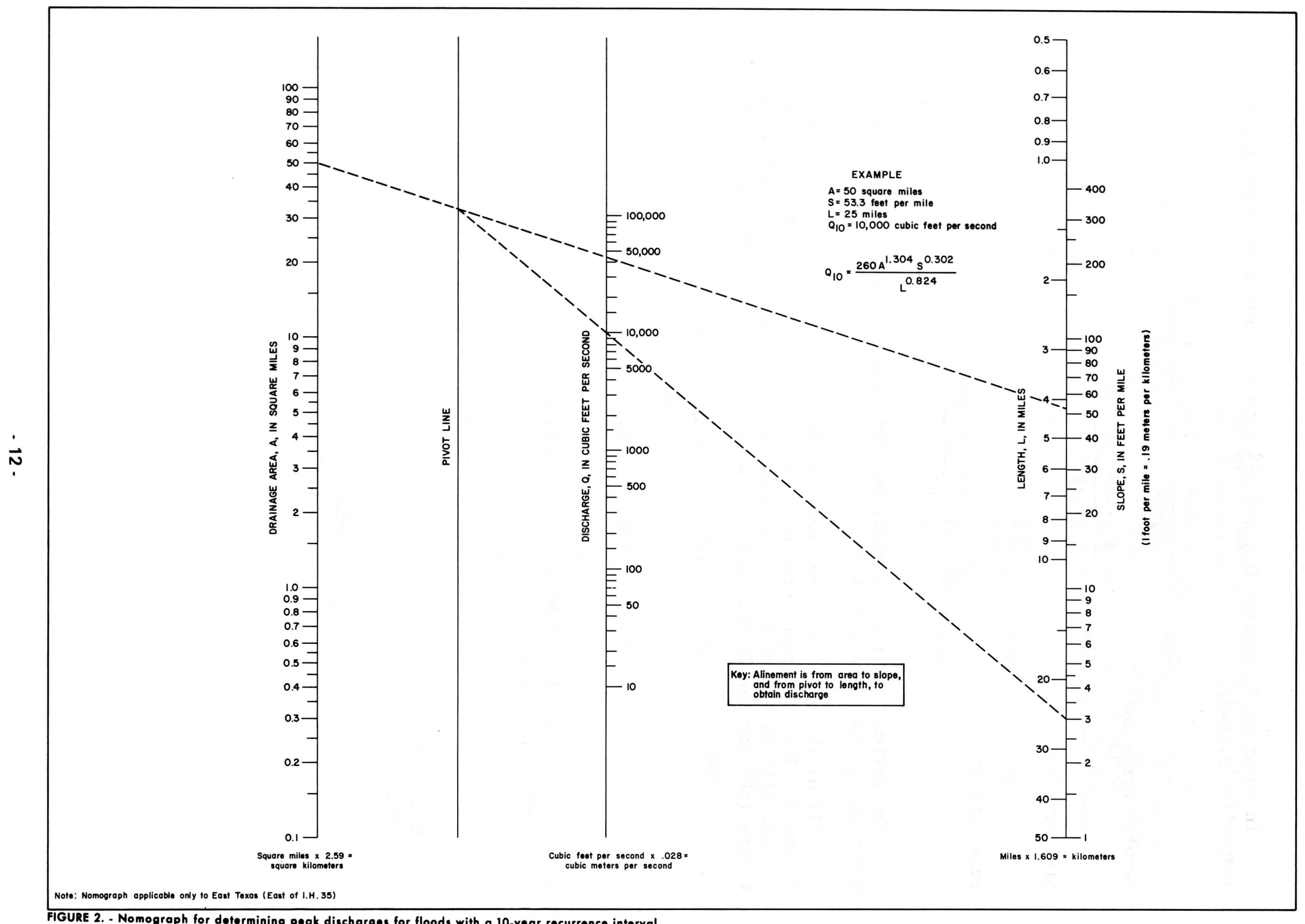

FIGURE 2. - Nomograph for determining peak discharges for floods with a 10 -year recurrence interval 


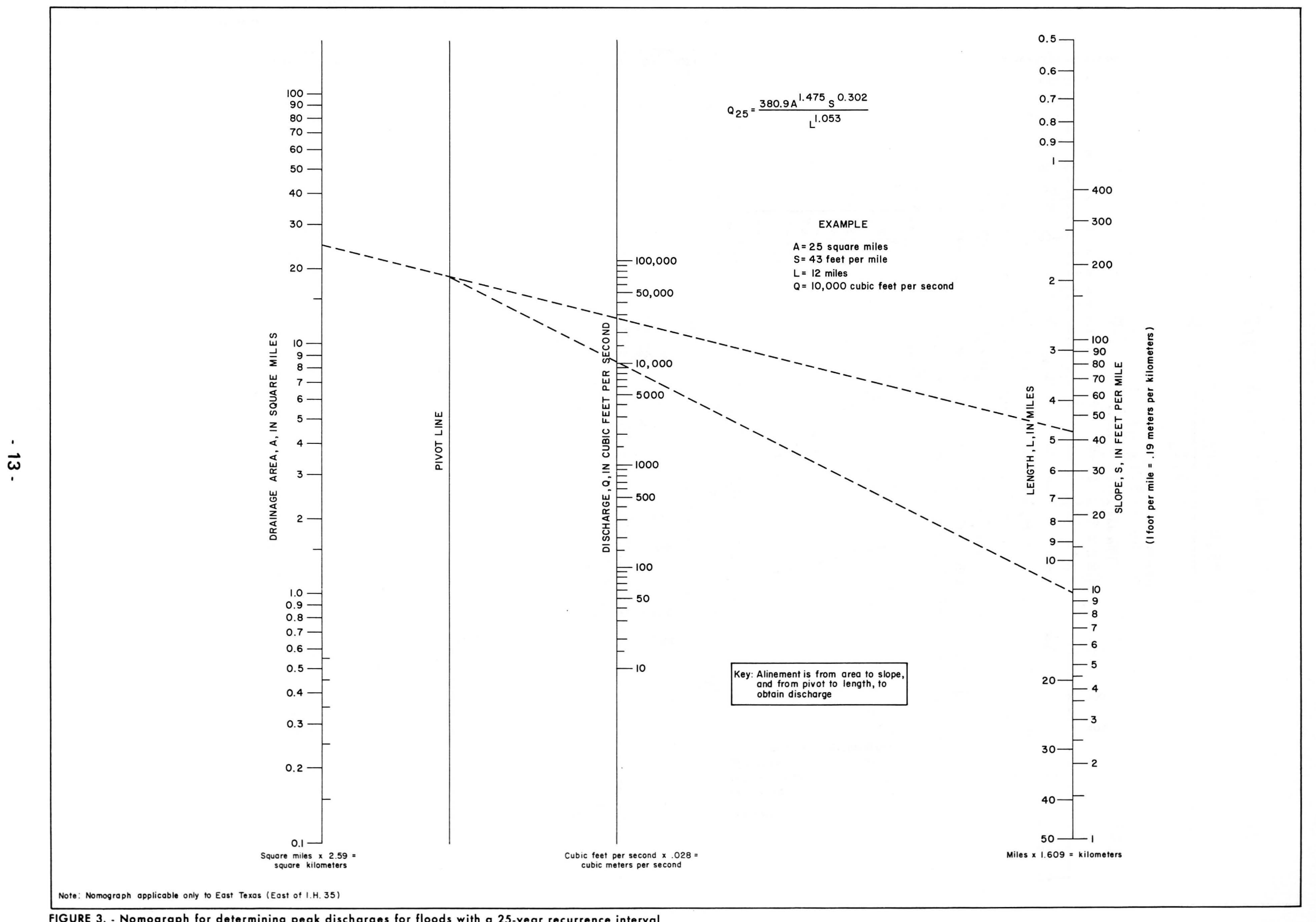

FIGURE 3. - Nomograph for determining peak discharges for floods with a 25 -year recurrence interval 


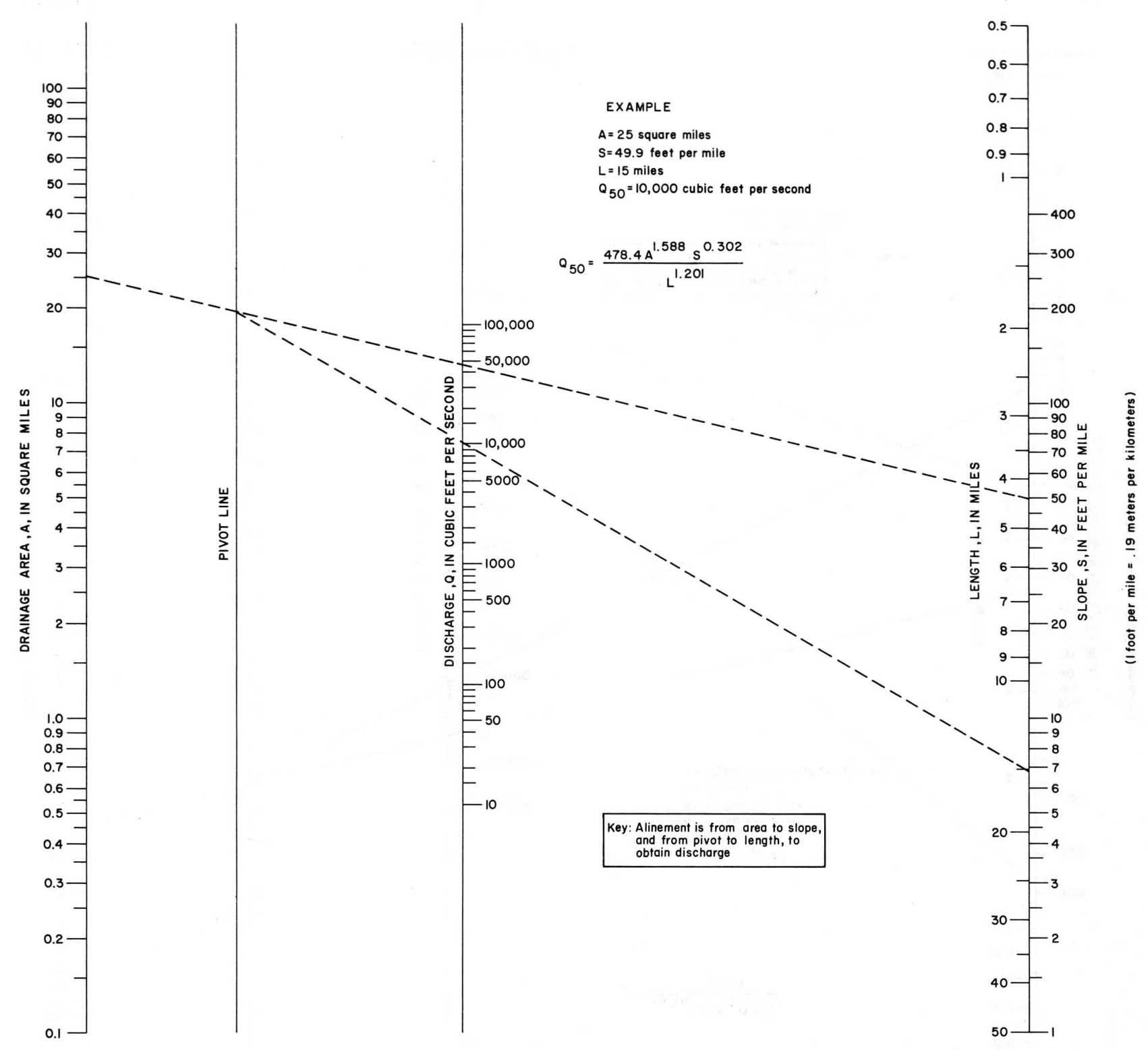

Square miles $\times 2.59=$

Miles $\times 1.609=$ kilometers 


$$
\begin{aligned}
& Q_{10}=8.138 \mathrm{~A}^{0.684}\left(\mathrm{~m}^{3} / \mathrm{s}\right) \\
& Q_{25}=\frac{7.22 \mathrm{~A}^{1.475} \mathrm{~S}^{0.302}}{\mathrm{~L}^{1.053}}\left(\mathrm{~m}^{3} / \mathrm{s}\right) \\
& Q_{50}=\frac{8.738 \mathrm{~A}^{1.588} \mathrm{~S}^{0.302}}{\mathrm{~L}^{1.201}}\left(\mathrm{~m}^{3} / \mathrm{s}\right)
\end{aligned}
$$

where $Q_{10}=$ the 10-year discharge, in cubic meters per second;

$\mathrm{Q}_{25}$ = the 25-year discharge, in cubic meters per second;

$Q_{50}=$ the 50-year discharge, in cubic meters per second;

$A=$ the drainage area, in square kilometers;

$\mathrm{L}=$ the length, in kilometers, of the main channel between the site and the basin divide, measured along the channel that drains the largest area; and

$S=$ the average slope, in meters per kilometer, between points 10 and 85 percent of the distance along the main channel from the site to the basin divide.

\section{SUMMARY}

The equations presented in this report provide a method that can be used to compute quickly the discharge for floods of selected recurrence intervals on sma11 nonregulated rural streams in a 100,000 square-mile $(259,000$ square-kilometer) area of East Texas. The user will be required to exercise judgment when applying the equations, which are applicable only to rural unregulated drainage areas ranging from 0.1 to 100 square miles ( 0.26 to 259 square kilometers) with the main-channel slope ranging from 1 to 200 feet per mile (0.19 to 38 meters per kilometer). These relations are preliminary and will be redefined after more data become available. 


\section{REFERENCES CITED}

Benson, M. A., 1964, Factors affecting the occurrence of floods in the Southwest: U.S. Geol. Survey Water-Supply Paper, p. D1-D72.

Dempster, G. R., Jr., 1974, Effects of urbanization on floods in the Dallas, Texas, metropolitan area: U.S. Geol. Survey Water Resources Investigation $60-73,55 \mathrm{p}$.

Gilbert, C. R., and Hawkinson, R. 0., 1971, A proposed streamflow-data program for Texas: U.S. Geol. Survey open-file rept., 52 p.

Johnson, S. L., and Sayre, D. M., 1973, Effects of urbanization on floods in the Houston, Texas metropolitan area: U.S. Geol. Survey Water Resources Investigation 3-73, $50 \mathrm{p}$.

Patterson, J. L., 1964, Magnitude and frequency of floods in the United States--Part 7, Lower Mississippi River basin: U.S. Geol. Survey Water-Supply Paper 1681, 636 p.

1965, Magnitude and frequency of floods in the United States--Part 8, Western Gulf of Mexico basins: U.S. Geol. Survey Water-Supply Paper 1682, 506 p. 



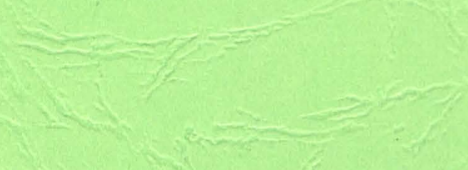

